\title{
PELAKSANAAN PEMBERIAN BANTUAN HUKUM TERHADAP TERDAKWA YANG TIDAK MAMPU DALAM PERKARA PIDANA DI KOTA BANDAR LAMPUNG
}

\section{The Implementation of the Giving of Legal Aid to Indigent Defendants to Criminal Case in Bandar Lampung}

\author{
Andry Rahman Arif \\ Jl. Pelita 1 Ujung, Labuhan Ratu, Bandar lampung \\ email: andryrahmanarif@yahoo.com
}

\begin{abstract}
Legal assistance is implemented through the courts, and legal aid legal aid program is provided in order to alleviate the burden of life for the people who cannot afford in terms of Economics, and is also useful to create justice and legal protection of the general public. Problems in this research is how the implementation of the granting of legal aid to defendants who cannot afford in terms of economy in criminal cases and the factors restricting implementation of granting legal aid to defendants who cannot afford in terms of economy in criminal cases. Based on the research results, and a discussion of the analysis of the implementation of legal aid to defendants who cannot afford in terms of economy in criminal cases, the implementation of the granting of legal aid can be done with the way through the courts, and the legal aid Institute ( $\mathrm{LBH}$ ) and can also be done by direct initiative of an advocate who voluntarily want to accompany her. Factors restricting implementation of granting legal aid to defendants who cannot afford in terms of economy in criminal cases among others; factors in law enforcement, community factors, cultural factors, facilities and infrastructure. Advice that can be given is the need for socializing by the court party, and about the implementation of the LBH granting legal assistance free of charge to the defendant who cannot afford, and to the need for sanctions to parties who caused the implementation of the grant of legal aid to the defendants engaged in criminal cases.
\end{abstract}

Keywords: Granting Of Legal Aid, the Defendant, Not Being Able To, Criminal Cases

abstrak

Bantuan hukum yang dilaksanakan melalui pengadilan, dan Lembaga Bantuan Hukum adalah merupakan program bantuan hukum yang diberikan 
dalam rangka meringankan beban hidup bagi golongan masyarakat yang tidak mampu dari segi ekonomi, dan juga berguna untuk menciptakan keadilan dan perlindungan hukum terhadap masyarakat umum. Permasalahan dalam penelitian ini adalah bagaimana pelaksanaan pemberian bantuan hukum terhadap terdakwa yang tidak mampu dari segi ekonomi dalam perkara pidana dan faktor-faktor penghambat pelaksanaan pemberian bantuan hukum terhadap terdakwa yang tidak mampu dari segi ekonomi dalam perkara pidana. Berdasarkan hasil penelitian, dan pembahasan mengenai analisis pelaksanaan pemberian bantuan hukum terhadap terdakwa yang tidak mampu dari segi ekonomi dalam perkara pidana, Pelaksanaan pemberian bantuan hukum dapat dilakukan dengan cara melalui pengadilan, dan Lembaga Bantuan Hukum (LBH) serta dapat juga dilakukan dengan inisiatif langsung dari seorang advokat yang secara sukarela mau mendampinginya. Faktor-faktor penghambat pelaksanaan pemberian bantuan hukum terhadap terdakwa yang tidak mampu dari segi ekonomi dalam perkara pidana antara lain; faktor penegak hukum, faktor masyarakat, faktor kebudayaan, faktor fasilitas sarana dan prasarana. Saran yang dapat diberikan yaitu perlunya sosialisasi oleh pihak Pengadilan, dan LBH tentang tata cara pelaksanaan pemberian bantuan hukum secara cuma-cuma terhadap terdakwa yang tidak mampu, dan diperlukannya pemberian sanksi kepada pihak-pihak yang menyebabkan terhambatnya pelaksanaan pemberian bantuan bantuan hukum terhadap terdakwa yang terlibat dalam perkara pidana.

\section{Kata Kunci: Pemberian Bantuan Hukum, Terdakwa, Tidak Mampu, Perkara Pidana}

\section{A. Pendahuluan}

Perjuangan masyarakat hukum Negara Republik Indonesia untuk memiliki suatu hukum acara pidana nasional, yang sesuai dengan hak asasi manusia dan terutama telah memperhatikan hak-hak tersangka dan terdakwa telah terwujud, ketika pada tanggal 31 Desember 1981 Pemerintah Indonesia memberlakukan Undang-Undang Nomor 8 Tahun 1981, yang dikenal dengan Kitab Undang-Undang Hukum Acara Pidana (KUHAP).

Disahkannya Undang Nomor 8 Tahun 1981 tentang KUHAP, maka diharapkan dapat menyelesaikan berbagai permasalahan yang ada di bidang hukum khususnya hukum pidana. KUHAP adalah master piece bangsa Indonesia dalam bidang hukum ${ }^{1}$, yang memberikan perlindungan Hak Asasi Manusia (HAM) yang sangat besar, dengan mengatur secara rinci hak-hak yang dimiliki dan dapat diperoleh bagi tersangka dan terdakwa selama

\footnotetext{
${ }^{1}$ Oemar Seno Adji, KUHAP Sekarang, (Jakarta: Erlangga, 1984), hlm. 55.
} 
proses pemeriksaan perkaranya berlangsung. Pemberian hak-hak kepada tersangka dan terdakwa tersebut sekaligus juga diikuti dengan pengaturan kewajiban tertentu kepada aparat penegak hukum, agar hak-hak tersangka dan terdakwa itu dapat terwujud dalam praktk pengadilan di Indonesia.

Proses pemeriksaan suatu perkara menurut KUHAP memiliki tujuan untuk menciptakan due process of law (proses hukum yang adil) dalam pemeriksaan perkara pidana. Hal ini sangat penting untuk dibuktikan di dalam praktik di muka pengadilan, sebab perlindungan HAM dalam proses hukum pidana tidak akan berarti apa-apa jika hak-hak yang telah dirumuskan di dalam KUHAP tidak dapat terlaksana dalam praktiknya. ${ }^{2}$ Perlindungan HAM bagi tersangka atau terdakwa, tidak diperbolehkan adanya diskriminasi dalam perlakuan, karena negara menjamin hak-hak individunya, satu-satunya hak yang boleh hilang dari seorang yang berstatus "tersangka" pelaku tindak pidana adalah hak atas kemerdekaan bergerak, karena undangundang memberi kewenangan kepada aparat penegak hukum untuk melakukan penangkapan dan penahanan atau perampasan kemerdekaan terhadap seorang tersangka atau terdakwa apabila telah ada bukti permulaan yang cukup. ${ }^{3}$

Beberapa hak tersangka atau terdakwa yang diatur oleh KUHAP, terdapat hak-hak yang sangat penting, yang minimal harus ada dalam suatu hukum acara modern, yaitu hak untuk mendapatkan bantuan hukum. Bantuan Hukum memiliki kedudukan yang cukup penting dalam setiap sistem peradilan pidana tidak terkecuali di Negara Indonesia. Secara umum dapat dikatakan bahwa bantuan hukum memunyai tujuan yang terarah pada bermacam-macam kategori sosial di dalam masyarakat. Konsep bantuan hukum berkaitan dengan hak-hak seseorang guna menjalankan hak-hak tersebut, oleh karenanya Bantuan Hukum dijalankan oleh para ahli hukum dan orang-orang yang berpengalaman dalam rangka untuk menjalankan profesinya. Bantuan hukum dijalankan oleh pemberi bantuan hukum yang berorientasi pada nilai-nilai kemulian, yaitu aspek kemanusiaan untuk memperjuangkan hak-hak manusia untuk hidup sejahtera dan berkeadilan.

Pemberian bantuan hukum tersebut dapat diberikan kepada semua orang tanpa membedakan status sosial seseorang. Hal tersebut adalah sebagaimana yang ada pada negara hukum (rechtsstaat) di mana negara mengakui dan melindungi hak asasi manusia setiap individu. Pengakuan negara terhadap hak individu ini tersirat di dalam persamaan kedudukan di hadapan hukum bagi semua orang.

${ }^{2}$ http://repository.UNAND.ac.id/16789/1/Thesis.pdf (Diakses Pada 4 Februari 2013 pukul 10:57 WIB).

${ }^{3}$ Mardjono Reksodiputro, Hak Asasi Manusia Dalam Sistem Peradilan Pidana, (Jakarta: Pusat Pelayanan Keadilan dan Pengabdian Hukum, 1994), hlm. 10. 


\section{B. Pembahasan}

\section{Pelaksanaan Pemberian Bantuan Hukum terhadap Terdakwa yang Tidak Mampu dari Segi Ekonomi dalam Perkara Pidana}

Pelaksanaan pemberian bantuan hukum tidak hanya dilaksanakan oleh seorang yang ahli di bidang hukum, dan berpengalaman dalam menjalankan profesinya, namun juga dapat berupa badan hukum yang telah memiliki kriteria-kriteria tertentu. Bantuan Hukum diberikan oleh pemberi bantuan hukum dalam hal ini adalah seorang advokat yang berorientasi pada nilainilai kemuliaan yakni aspek kemanusiaan untuk memperjuangkan hak-hak manusia agar dapat hidup sejahtera dan berkeadilan khususnya di lembaga peradilan. Bantuan hukum merupakan suatu media yang dapat digunakan oleh semua lapisan masyarakat dalam rangka menuntut haknya atas adanya perlakuan yang tidak sesuai dengan kaidah-kaidah hukum yang berlaku.

Bantuan Hukum yang diberikan oleh seorang advokat kepada penerima bantuan hukum haruslah memenuhi syarat-syarat tertentu yang telah ditentukan dalam peraturan perundang-undangan, dengan adanya seorang advokat yang mendampingi, dan membela tersangka atau terdakwa sejak saat terjadinya penangkapan atau penahanan sampai dengan proses pemeriksaan perkara di persidangan adalah untuk menghindari perlakuan yang sewenang-wenang dari pihak petugas yang tidak bertanggung jawab.

Penyelenggaran, dan pemberian bantuan hukum secara cuma-cuma bagi golongan masyarakat yang tidak mampu dapat ditempuh melalui dua cara yaitu:

a. pelaksanaan bantuan hukum melalui Pengadilan Negeri.

b. Pelaksanaan bantuan hukum melalui Lembaga Bantuan Hukum (LBH).

Menurut hakim Moch $\mathrm{Ali}^{4}$ menyatakan bahwa pelaksanaan pemberian bantuan hukum bagi terdakwa yang tidak mampu oleh Pengadilan Negeri dilakukan dengan cara melalui penetapan oleh ketua hakim majelis yang menangani perkara tersebut berkonsultasi dengan Ketua Pengadilan untuk menunjuk seorang advokat melalui Pos Bantuan Hukum (Posbakum).

Pelaksanaan pemberian bantuan hukum oleh Posbakum dilakukan dengan cara memberikan arahan kepada terdakwa yang tidak mampu untuk melengkapi administrasi dengan cara melampirkan surat keterangan tidak mampu dari pejabat kelurahan atau kepala desa di lingkungan tempat terdakwa tinggal, atau Surat Keterangan Tunjangan Sosial lainnya seperti Kartu Keluarga Tidak mampu (KKM), Kartu Jaminan Kesehatan Masyarakat (Jamkesmas), Kartu Program Keluarga Harapan (PKH), dan Kartu Bantuan Langsung Tunai (BLT); atau Surat Pernyataan tidak mampu membayar jasa advokat yang dibuat, dan ditandatangani oleh Pemohon

\footnotetext{
${ }^{4}$ Hasil wawancara dengan Bapak Moch Ali sebagai hakim Pengadilan Negeri Tanjung Karang tanggal 4 April 2013 Pukul 13.00 di Pengadilan Negeri Tanjung Karang.
} 
Bantuan Hukum, serta diketahui oleh Ketua Pengadilan Negeri, kemudian mengajukan permohonan secara tertulis yang berisi sekurang-kurangnya identitas pemohon, dan uraian singkat mengenai pokok persoalan yang dimohonkan Bantuan Hukum, serta menyerahkan dokumen yang berkenaan dengan perkara yang sedang dijalani.

Menurut advokat Herwanto Semenguk ${ }^{5}$ menyatakan bahwa pelaksanaan pemberian bantuan hukum bagi terdakwa yang tidak mampu oleh Lembaga Konsultasi Bantuan Hukum (LKBH) tidak hanya diberikan pada saat seseorang tersebut berstatus sebagai terdakwa, tetapi juga diberikan pada saat seseorang ditetapkan menjadi tersangka. Apabila seorang tersangka atau terdakwa mengiginkan jasa bantuan hukum dari LKBH secara cuma-cuma, maka dapat dilakukan dengan cara melampirkan semua berkas yang meliputi surat permohonan secara tertulis yang berisi sekurangkurangnya identitas pemohon, dan uraian singkat mengenai pokok persoalan yang dimohonkan Bantuan Hukum, menyerahkan dokumen yang berkenaan dengan perkara, serta melampirkan surat keterangan tidak mampu dari lurah, kepala desa, atau pejabat yang setingkat di tempat tinggal pemohon Bantuan Hukum, dan apabila tidak mendapatkannya, maka diperkenankan untuk menggunakan surat menyurat lain yang dapat membuktikan bahwasannya pemohon bantuan hukum tersebut tidak mampu.

Surat menyurat lain yang dimaksud oleh Herwanto Semenguk adalah seperti jamkesmas, jamkesda, askeskin, ataupun gakin yang mana surat-surat tersebut adalah akan menjadi alat bukti yang cukup untuk menyatakan bahwasannya seorang pemohon bantuan hukum, dalam hal ini terdakwa tersebut memang tidak mampu dari segi ekonomi, kemudian pihak LKBH akan membentuk tim khusus untuk menetapkan advokat yang akan mendampingi terdakwa, setelah ditetapkannya seorang advokat yang akan mendampingi terdakwa, maka seorang pengacara atau advokat tersebut harus mendampingi terdakwa sampai dengan perkaranya selesai.

Menurut Maroni ${ }^{6}$ bahwa dalam pemberian bantuan hukum secara cuma-cuma dapat dilakukan dengan dua cara yakni bisa melalui Pengadilan dan Lembaga Bantuan Hukum (LBH) baik yang dikelola oleh pihak swasta maupun yang dikelola oleh pihak Universitas. Pemberian Bantuan Hukum yang dilakukan haruslah berpedoman pada Undang-Undang No 16 Tahun 2011 Tentang Bantuan Hukum, yakni:

\footnotetext{
${ }^{5}$ Hasil wawancara dengan Bapak Herwanto Semenguk sebagai advokat Lembaga Konsultasi dan Bantuan Hukum Lentera Cendikia (LKBH LC) tanggal 28 Maret 2013 Pukul 14.30 di Sekretariat LKBH LC.

${ }^{6}$ Hasil wawancara pada tanggal 1 April 2013 pukul 10.00 di Gedung C Lantai 1 ruang dosen bagian Hukum Pidana Universitas Lampung.
} 
a) mengajukan permohonan secara tertulis yang berisi sekurang-kurangnya identitas pemohon dan uraian singkat mengenai pokok persoalan yang dimohonkan Bantuan Hukum;

b) menyerahkan dokumen yang berkenaan dengan perkara; dan

c) melampirkan surat keterangan tidak mampu dari lurah, kepala desa, atau pejabat yang setingkat di tempat tinggal pemohon Bantuan Hukum.

Apabila semua persyaratan di atas telah dilengkapi, barulah seorang terdakwa yang tidak mampu dari segi ekonomi bisa untuk mendapatkan bantuan hukum secara cuma-cuma yang diselenggarakan oleh pihak Pengadilan maupun pihak Lembaga Bantuan Hukum (LBH).

\section{Faktor-Faktor Penghambat Pelaksanaan Pemberian Bantuan Hukum terhadap Terdakwa yang Tidak Mampu dari Segi Ekonomi dalam Perkara Pidana}

Bantuan hukum adalah hak bagi seorang terdakwa yang tidak mampu sudah diatur secara rinci dalam peraturan perundang-undangan, hal ini bukan berarti bahwa terdakwa dapat dengan mudah memperoleh bantuan hukum dari advokat dalam penegakan ide bantuan hukum tersebut menjadi suatu kenyataan, akan tetapi terdapat juga beberapa faktor penghambat yang akan mempengaruhinya.

Faktor-faktor yang menghambat penegakan hukum khususnya dalam hal bantuan hukum menurut Soerjono Soekanto adalah sebagai berikut: ${ }^{7}$

a. faktor hukumnya sendiri yaitu berupa undang-undang;

b. faktor penegak hukum, yakni pihak-pihak yang membentuk maupun yang menerapkan hukum;

c. faktor sarana atau fasilitas yang mendukung penegakan hukum;

d. faktor masyarakat, yakni lingkungan di mana hukum tersebut berlaku atau diterapkan; dan

e. faktor kebudayaan, yakni sebagai hasil karya, cipta dan rasa yang didasarkan pada karsa manusia di dalam pergaulan hidup.

Menurut Moch Ali, mengatakan bahwa bagi pihak pengadilan untuk menunjuk seorang advokat tidak mengalami suatu hambatan yang berarti, sebab advokat yang ditunjuk pihak pengadilan selama ini senantiasa siap, dan bersedia untuk mendampingi terdakwa selama proses persidangan, apabila ada mungkin hanya advokat yang sudah ditunjuk oleh pengadilan tidak bersedia, akan tetapi pada umumnya para advokat yang telah ditunjuk oleh pengadilan senantiasa bersedia. Beliau mengatakan hal yang menjadi penghambat dari pelaksanaan pemberian bantuan hukum untuk masyarakat

\footnotetext{
${ }^{7}$ Soerjono Soekanto, Faktor-Faktor Yang Mempengaruhi Penegakan Hukum, (Jakarta: PT Raja Grafindo Persada), hlm. 3.
} 
yang tidak mampu adalah dipengaruhi oleh minimnya dana bantuan hukum yang disediakan oleh Pemerintah melalui Kementerian Hukum dan HAM. Dana yang diberikan kepada pihak Pengadilan tersebut masih belum cukup untuk memenuhi kebutuhan akan pendanaan kepada para advokat, agar bersedia untuk memberikan bantuan hukumnya secara cuma-cuma kepada masyarakat yang tidak mampu melalui Pos Bantuan Hukum (Posbakum) yang ada di tingkat Pengadilan Negeri. Menurut Herwanto Semenguk faktorfaktor yang menjadi penghambat dalam pelaksanaan pemberian bantuan hukum terhadap terdakwa yang tidak mampu yakni:

\section{a. Faktor Masyarakat}

Pengertiannya adalah indikator dari sebuah keefektifan suatu hukum dapat dilihat dari tingkat pengetahuan masyarakat mengenai suatu hukum tersebut yang mana dalam hal ini adalah bantuan hukum. Pada umumnya masyarakat yang tidak mampu dari segi ekonomi tidak begitu paham dengan adanya bantuan hukum secara cuma-cuma yang akan diberikan oleh seorang advokat, sebagian masyarakat tidak mampu tidak mau menggunakan jasa advokat, karena menurut pemikiran mereka apabila menggunakan jasa advokat, maka memerlukan biaya yang relatif besar. Hal ini mengakibatkan tidak semua masyarakat tidak mampu yang berperkara baik pidana maupun perdata bisa mendapatkan bantuan hukum.

\section{b. Faktor Kebudayaan}

Pengertiannya adalah masyarakat umum memiliki anggapan bahwasannya apabila ingin didampingi oleh seorang advokat, maka harus menyediakan sejumlah uang yang tidak sedikit, kemudian terlalu banyak administrasi yang harus dilengkapi, sehingga kebanyakan dari orang yang tidak mampu pada akhirnya tidak bersedia untuk didampingi oleh seorang advokat. Hal ini sudah merupakan suatu paradigma yang sudah melekat pada masyarakat terhadap bantuan hukum, dan sudah menjadi suatu kebudayaan yang tumbuh di masyarakat, sehingganya masih saja ditemukannnya kasus orang yang tidak mampu yang tidak didampingi oleh seorang advokat dalam proses peradilan yang dijalaninya, walaupun pada kenyataannya bantuan hukum secara gratis atau cuma-cuma memang benar adanya, dan juga telah diatur dalam peraturan perundang-undangan.

Menurut Maroni pemberian bantuan hukum terhadap terdakwa yang tidak mampu akan dipengaruhi berbagai faktor, yaitu:

1) Faktor Penegak Hukum

Pihak-pihak yang menerapkan hukum bagi seorang advokat yang menolak memberikan bantuan hukum secara cuma-cuma secara garis besar 
belum ada yang dikenakan sanksi yang tegas dari pihak yang berwenang untuk melakukannya. Sesuai dengan PP No 83 tentang Persyaratan dan Tata Cara Pemberian Bantuan Hukum Secara Cuma-Cuma telah menjelaskan bahwa bagi advokat yang tidak bersedia untuk memberikan bantuan hukum, maka akan diberikan sanksi berupa:

a) teguran lisan;

b) teguran tertulis;

c) pemberhentian sementara dari profesinya selama 3 (tiga) sampai dengan

12 (dua belas) bulan berturut-turut; atau

d) pemberhentian tetap dari profesinya.

Pada kenyataannya sanksi yang tegas belum bisa diterapkan kepada advokat yang menolak untuk memberikan bantuan hukumnya secara cumacuma, sehingganya proses penegakan hukum bagi para advokat yang menolak memberikan bantuan hukum secara cuma-cuma kepada masyarakat yang tidak mampu baik yang ada di lingkungan Pengadilan maupun yang ada di Lembaga Bantuan Hukum (LBH) belum bisa berjalan dengan baik.

2) Kurangnya Fasilitas atau Sarana dan Prasarana

Masih kurangnya sosialisasi yang dilakukan baik oleh pihak Pengadilan, maupun LBH mengenai pemberian bantuan hukum secara cuma-cuma kepada masyarakat yang tidak mampu khususnya di daerah pelosok, karena kurangnya sarana dan prasarana untuk menuju tempattempat tersebut. Hal ini mengakibatkan sebagian besar dari masyarakat khususnya yang tidak mampu belum mengetahui akan adanya pemberian bantuan hukum secara cuma-cuma, kemudian keterbatasan dana yang disediakan oleh Pemerintah menjadi salah satu penyebab kurangnya sosialisasi mengenai pemberian bantuan hukum secara cuma-cuma kepada masyarakat di daerah-daerah terpencil.

\section{Penutup}

Pelaksanaan Pemberian Bantuan Hukum terhadap terdakwa yang tidak mampu dari segi ekonomi dalam perkara pidana dapat ditempuh dengan cara yaitu melalui Pengadilan Negeri, dan melalui Lembaga Bantuan Hukum (LBH). Pelaksanaan bantuan hukum di Pengadilan dilakukan dengan cara penetapan seorang advokat yang dilakukan oleh ketua hakim majelis yang menangani perkara tersebut berkonsultasi dengan Ketua Pengadilan untuk menunjuk seorang advokat melalui Pos Bantuan Hukum (Posbakum), setelah itu terdakwa membuat surat kuasa kepada seorang advokat dan melengkapi semua kelengkapan berkas-berkas perkara, barulah kemudian dapat didampingi oleh advokat.

Pemberian bantuan hukum yang diberikan kepada terdakwa haruslah orang-orang yang tidak mampu, dan kritetia seseorang dikatakan tidak 
mampu adalah dengan melampirkan surat keterangan tidak mampu dari kepala desa atau kelurahan setempat, sedangkan pelaksanaan bantuan hukum di LBH dilaksanakan dengan cara melampirkan semua berkas yang meliputi surat permohonan secara tertulis yang berisi identitas pemohon, dan uraian singkat mengenai pokok persoalan yang dimohonkan bantuan hukum, menyerahkan dokumen yang berkenaan dengan perkara, serta melampirkan surat keterangan tidak mampu dari pejabat yang berwenang di tempat tinggal pemohon bantuan hukum, dan apabila tidak mendapatkannya, maka diperkenankan untuk melampirkan surat menyurat lain yang dapat membuktikan bahwasannya pemohon bantuan hukum tersebut tidak mampu.

Faktor-faktor penghambat pelaksanaan pemberian bantuan hukum terhadap terdakwa yang tidak mampu dari segi ekonomi dalam perkara pidana adalah: faktor penegak hukum, faktor fasilitas sarana dan prasarana, faktor masyarakat, dan faktor kebudayaan.

\section{Daftar Pustaka}

\section{A. Buku}

Abdurrahman, 1983, Aspek-Aspek Bantuan Hukum Di Indonesia, Yogyakarta: Cendana Press.

Adji, Oemar Seno, 1984, KUHAP Sekarang, Jakarta: Erlangga.

Hamzah, Andi, 1986, Perlindungan Hak-Hak Asasi Manusia Dalam Kitab Undang-Undang Hukum Pidana, Jakarta: Ghalia.

Kusumaatmadja, Mochtar, 1999, Pengantar Ilmu Hukum, (Suatu Pengenalan Pertama Ruang Lingkup Berlakunya Ilmu Hukum), cet. I, Bandung: PT Alumni.

Michael, Donny, 2012, Peran Pemerintah Daerah Dalam Pemenuhan Hak Atas Keadilan (Studi Tentang Akses Bantuan Hukum Bagi Masyarakat Tidak mampu Di Provinsi Jawa Timur). Jurnal HAM. (Online), Volume 3, No. 2.

Nasution, Adnan Buyung, 1981, Bantuan Hukum Di Indonesia, Jakarta: LP3ES.

Kedua, Jakarta: LP3ES.

1982, Bantuan Hukum Di Indonesia, Cetakan

Pandu, Yuda, 2004, Klien Dan Advokat, Jakarta: Abadi.

Reksodiputro, Mardjono, 1994, Hak Asasi Manusia Dalam Sistem Peradilan

Pidana, Jakarta: Pusat Pelayanan Keadilan dan Pengabdian Hukum. 1997, Hak Asasi Manusia Dalam Sistem Peradilan

Pidana, Buku Ketiga, Edisi Pertama Cetakan Kedua, Jakarta: Pusat Pelayanan Keadilan Dan Pelayanan Keadilan Dan Pengabdian Hukum Universitas Indonesia. 
Soekanto, Soerjono, 1983, Bantuan Hukum Suatu Tinjauan Sosio Yuridis, Jakarta: Ghalia Indonesia. , 1986, Pengantar Penelitian Hukum, Jakarta: UI Press. ,2002, Faktor-Faktor Yang Mempengaruhi Penegakan

Hukum, Jakarta: PT Raja Grafindo Persada.

Soemitro, Roni Hanitijo, 1998, Metode Penelitian Hukum Dan Jurimentri, Jakarta: Ghalia Indonesia.

Sunggono, Bambang dan Harianto, Aries, 2001, Bantuan Hukum dan Hak Azasi Manusia, Bandung: Mandar Maju.

Tarif, S, 1976, Pemberian Bantuan Hukum Oleh Fakultas Hukum Negeri, Dan Kepengacaraan, Dalam Pemberian Bantuan Hukum Oleh Fakultas Hukum Negeri, Jakarta: Departemen Penerangan.

Tim Penyusun Kamus, 1991, Pembinaan Dan Pengembangan Bahasa. Kamus Besar Bahasa Indonesia, Balai Pustaka, Jakarta.

Widodo, J, Fajar, 2004, Ligitasi Dan Bantuan Hukum, Bagian Hukum Pidana Fakultas Hukum, Bandar Lampung: Universitas Lampung.

Wiranata, Frans Hendra, 2000, Bantuan Hukum Suatu Bentuk Hak Asasi Manusia Bukan Belas Kasihan, Jakarta: PT Elex Media Komputindo Kelompok Gramedia.

YLBHI \& PSHK, 2006, Panduan Bantuan Hukum Di Indonesia, Cetakan ke 1, Jakarta: YLBHI.

\section{B. Peraturan Perundang-Undangan}

Undang-Undang Dasar 1945.

Undang-Undang No 8 Tahun 1981, Kitab Undang-Undang Hukum Acara Pidana (KUHAP).

Undang-Undang No 39 Tahun 1999 Tentang Hak Asasi Manusia.

Undang-Undang No 18 Tahun 2003 Tentang Advokat.

Undang-Undang No 48 Tahun 2009 Tentang Kekuasaan Kehakiman.

Undang-Undang No 16 Tahun 2011 Tentang Bantuan Hukum.

PP No 83 Tahun 2008 Tentang Persyaratan Dan Tata Cara Pemberian Bantuan Hukum Secara Cuma-Cuma.

Instruksi Menteri Kehakiman M.01-UM.08.10 Tahun 1996 Tentang Petunjuk Pelaksanaan Program Bantuan Hukum Bagi Masyarakat Yang Kurang Mampu Melalui Pengadilan Negeri dan Pengadilan Tata Usaha Negara.

Dirjen Pembinaan Badan Peradilan Umum, 1985.

\section{Dokumen}

Putusan Pengadilan Negeri Kota Metro Nomor :38/ Pid. B / 2011/ PN.M 


\section{Website}

http://asa2009.blogspot.com/2012/03/pengertian-dan-prosedur-perkarapidana.html.

http://edukasi.kompasiana.com/2011/04/01/istilah-istilah-dalam-penelitianilmiah 352239.html.

http://elib.unikom.ac.id/files/disk1/607/jbptunikompp-gdl-herwinsusa30310-9-unikom_h-i.pdf

http://hukum.kompasiana.com/2012/08/06/mengurai-uu-bantuan-hukum-1482891.html.

http://id.scribd.com/doc/79328103/Analisis-Kasus-Nenek-Minah.

http://isjd.pdii.lipi.go.id/admin/jurnal/20308547558.pdf.

http://nizarakbar.blogspot.com/2012/05/pengertian-dan-definisi-ekonomimenurut.html.

http://repository.UNAND.ac.id/16789/1/Thesis.pdf.

http://repository.usu.ac.id/bitstream/123456789/22091/4/Chapter\%20II.pdf. http://www.hukumonline.com/pentingnya-kehadiran-pembela-hukum-dankeadilan.

http://www.sentra-edukasi.com/2009/08/materi-bindo-definisi-pengertianarti_8059.html.

http://www.tanyahukum.com/uncategorized/179/jenis-bantuan-hukum-diindonesia. 